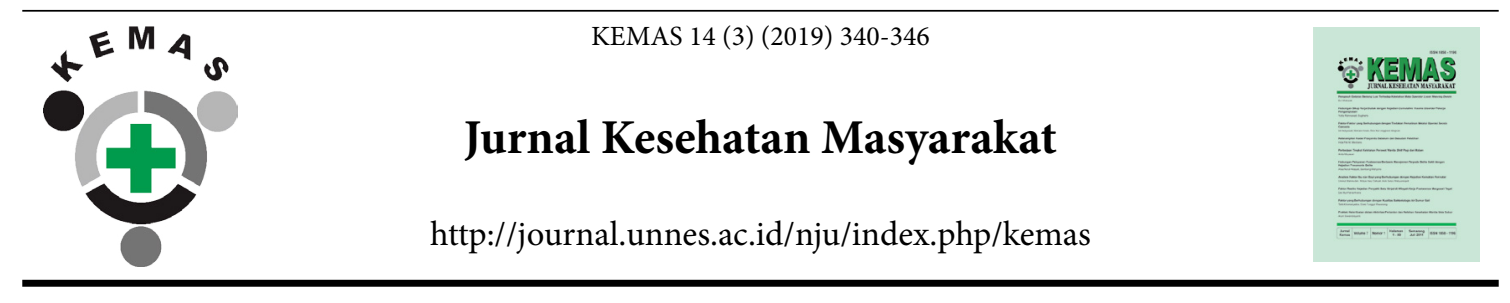

\title{
Sexual Behaviours for Contracting Sexually Transmitted Infections and HIV at Badung Traditional Market, Bali
}

\author{
Luh Gede Pradnyawati ${ }^{1 \bowtie}$, Luh Seri Ani² , Pande Putu Januraga ${ }^{3}$ \\ ${ }^{1}$ Faculty of Medicine and Health Sciences, Warmadewa University, Indonesia \\ ${ }^{2}$ Department of Community and Preventive Medicine Faculty of Medicine Udayana University, Indonesia \\ ${ }^{3}$ Center for Public Health Innovation, Udayana University, Indonesia
}

\begin{tabular}{l} 
Article Info \\
\hline Article History: \\
Submitted March 2018 \\
Accepted February 2019 \\
Published March 2019 \\
\hline Keywords: \\
sexual behaviours, \\
STIs, HIV/AIDS, \\
women, market workers \\
\hline DOI \\
https://doi.org/10.15294/ \\
kemas.v14i3.13733
\end{tabular}

\begin{abstract}
Studies on sexual behaviours are mainly conducted among high risk populations, only limited publications from female general population. This study aims to explore sexual behaviours among women who work at the biggest traditional market in Bali Province. A mix-methods approach was used to study women who work at the Badung Market in Bali. In October 2016, a survey of 100 women was conducted, then followed by a total of 20 in-depth interviews. Quantitative data were analysed using descriptive statistic, while qualitative data were analysed using thematic approach. Our survey found that $60 \%$ of respondents were perceived themselves as a low risk group. As many as $22 \%$ of respondents admitted that they had sexual intercourse with more than one partner over the last years with $41 \%$ of them used condom on their last sexual intercourse. In-depth interviews revealed that the basis of their sexual intercourse was mutual interests and desire. Only one respondent admitted economic reasons for sexual intercourse. Condoms were rarely used because of low risk perception of the sexual intercourse. Prevention programs targeting low risk groups are required to reduce the burden of disease from STIs including HIV.
\end{abstract}

\section{Introduction}

Sexually transmitted infections (STIs) are one of the public health concerns globally, both in developed and developing countries (Purnamawati, 2013). STIs are a variety of infections that can be transmitted from one person to another through sexual contact (Aryani, 2015). The incidence and prevalence of STIs are unknown (Purnamawati, 2013). At least 250 million new cases are documented every year globally and this figure tends to increase from time to time.

A high number of STI cases have been reported among high risk population groups. Indonesia is the fifth largest developing country in Asia which has a high risk of HIV / AIDS, which has high mortality rate (Kemenkes RI, 2014). Risk factors for transmission of HIV / AIDS in Indonesia are heterosexuals (86.4\%), homosexuals $(4.8 \%)$, drug users injection (2.6\%), and perinatal transmission (3.6\%). High risk population that include female sex workers (FSWs), men who have sex with men (MSM), and transgender, however, several reports have also revealed that population who previously considered as low risk groups for example housewives and women who work at the local markets are also found to have HIV/AIDS and STIs. The highest cases of HIV and AIDS based on regencies / cities in the province of Bali until October 2013 were found in Denpasar City with the number of HIV cases reaching 1.644 cases

\footnotetext{
Correspondence Address:

Faculty of Medicine and Health Sciences, Warmadewa University, Bali.

Email : pradnyawati86@gmail.com
}

pISSN 1858-1196 eISSN 2355-3596 
(Dinkes Provinsi Bali, 2013). Bali Provincial Health Office in 2016 reported that 582 patients with STIs and HIV/AIDS were from low risk groups, in which Denpasar District contributed the most with total cases of 336 patients (Dinkes Provinsi Bali, 2017).

Market is a site where high risk behaviours among the general population may take place. Badung Market, the biggest traditional market located in Denpasar City, is the centre of trading and mobilization of goods. All traders in this market are changing over time from early morning, afternoon, and night time. Traders or people who work at the markets may came from a low education level background and may also separated from their regular partner. These may contribute to vulnerability for contracting STIs, especially among women who work at the markets.

A quantitative study on the vulnerability of women for contracting STIs and HIV has been conducted at three different locations in Denpasar City. This study found that several factors contribute to women vulnerability for contracting STIs and HIV were multiple sexual partners, low bargaining position for condom use, and prostitution (Dewi et al, 2013). An explorative study by employing both survey and qualitative approaches is required to further explore high risk sexual behaviours among women who work at the Badung Market. Findings from this study can be utilised to improve STIs and HIV prevention program for women, especially for those who work in the market.

\section{Methods}

An explorative study by employing a mixmethods quantitative preliminary approach was conducted in the Badung Market - Denpasar City. This approach was chosen because it firstly aimed to understand descriptive characteristics of participant and then followed by a qualitative inquiry to understand experiences of participant and social contexts where these experiences were embedded.

We conducted a survey using a quota sampling of 100 respondents. We collected the data by a structured interview assisted by a questionnaire. The data collected included social-economic variables, sexual behaviours, perceived risk for contracting HIV and STIs including its prevention measures. In addition, a total of 20 in-depth interviews were also conducted to explore further their sexual behaviours, perceived risk for contracting HIV and STIs including its prevention measures. The data were collected in October 2016 at the Badung Market-Denpasar City. The data were collected from sexually active women aged between 18-45 years who worked at the market either as the owner of goods/shop, shop assistant, and market labourer.

Quantitative data were analysed on STATA, while qualitative data were analysed thematically using a qualitative-verification technique. This study protocol has been approved by the Human Research Ethic Committees, Faculty of Medicine Udayana University and Sanglah General Hospital Denpasar. All respondents were provided with the participant information sheet and written informed consents were obtained prior to data collection. Confidentiality and anonymity were guaranteed and only coded initials were used in the report and in all published materials.

\section{Results and Discussions}

Our survey found that the majority of respondents were Balinese (83\%), married (88\%), with an average income of IRD 15.5 million per year and an average working period of nine years. Most of respondents were came from low to moderate educational bakgrounds where the majority was primary school graduates (36\%). Based on the area of origin, most of respondents were from Karangasem District (37\%) followed by Denpasar City (11\%) and Singaraja District (8\%).

Further analysis showed that as many as $14 \%$ married respondents were lived with other man but not their husband (see Table 1). About $22 \%$ of respondents reported that they had sex with other man in the last year and about 5\% of respondents had sex with multiple partners in the last year (see Table 2). One respondent reported that she received gifts or money from her sexual partner.

Our study is the first which employs two data collection techniques to explore sexual behaviours and perceived risk for contracting HIV and STIs among women who work at the markets in Indonesia. Our quantitative and qualitative inquiries found that risky sexual 
Table 1. Distribution Frequency of Marital Status and Living Arrangement of Respondents

\begin{tabular}{l|l}
\hline Marital status & $\mathrm{f}(\%)$ \\
\hline Married and stayed with husband & $74(74.0)$ \\
Married and stayed with other man & $14(14.0)$ \\
Not married and not stayed with their sexual partner & $12(12.0)$ \\
\hline
\end{tabular}
Source: Primary Data. 2016

Table 2. Distribution Frequency of Sexual Behaviours Over the Last 12 Months

\begin{tabular}{lll}
\hline & Number of partner(s) & $\mathrm{f}(\%)$ \\
\cline { 2 - 3 } & One & $17(17.0)$ \\
Having sex with other man outside of marriage and & Two & $2(2.0)$ \\
stay with him but did not received any gifts or money & Three & $3(3.0)$ \\
& Don't have & $78(78.0)$ \\
\cline { 2 - 3 } & Total & $100(100.0)$ \\
\cline { 2 - 3 } Having sex with other man and received gifts or money & One & $1(1.0)$ \\
from their sexual partner (commercial partner) & Don't have & $99(99.0)$ \\
\cline { 2 - 3 } & Total & $100(100.0)$ \\
\hline
\end{tabular}

Source: Primary Data. 2016

Table 3. Distribution Frequency of Condom Use on The Last Sexual Intercourse to Prevent HIV and STIs

\begin{tabular}{lll}
\hline Condom use & & $\mathrm{f}(\%)$ \\
\hline \multirow{2}{*}{ Condom use with commercial partner } & Yes & $0(0.0)$ \\
& No & $100(100.0)$ \\
\hline \multirow{2}{*}{ Condom use with other man (outside of marriage) but not } & Total & $100(100.0)$ \\
commercial partner & No & $59(59.0)$ \\
& Total & $41(41.0)$ \\
\end{tabular}

Source: Primary Data. 2016

behaviours exist among women who work at the market. Most of our respondents performed sexual intercourse outside of their marriage as well as sexual intercourse with multiple sexual partners. They came to agreement for sexual intercourse on the basis of mutual interest or desire. Our study revealed that as many as $22 \%$ of women who worked at the market had sexual intercourse with their affair and stayed with them. These women did not receive gifts or money from their sexual relation with their affair.

Women in our study admitted that they were rarely used condom on their last sexual intercource with their affair. As many as $41 \%$ of our respondents reported that they were not used condom on their last sexual intercourse with their affair. However, our survey revealed that $60 \%$ of our respondents believed that they were at low risk for contracting HIV or STIs.

From all respondents who had regular sexual partner outside their husband, 59\% were not used condom on the last sexual intercourse. One respondent who had sex with her commercial partner was also not used condom on the last sexual intercourse (see Table 3). Survey on their perceived risk for contracting HIV and STIs revealed that $60 \%$ of respondents believed that they were not at risk for contracting HIV and STIs, about 39\% respondents felt that they were on probable or moderate risk for contracting HIV and STIs. Only $1 \%$ of respondents believed that they were at high risk for contracting HIV and STIs (see Table 4).

Badung Market in Denpasar City has 
Table 4. Distribution Frequency of Respondent's Perceived Risk for Contracting HIV and STIs

\begin{tabular}{ll}
\hline Risk for HIV and STIs transmission & $\mathrm{f}(\%)$ \\
\hline No risk & $60(60.0)$ \\
Probable or moderate risk & $39(39.0)$ \\
At high risk & $1(1.0)$ \\
At very high risk & $0(0.0)$ \\
\hline
\end{tabular}

Source: Primary Data. 2016

evolved as a social interaction space between local communities and migrants' due to high mobilization of people. Groups that previously considered as a low risk population is now becoming more vulnerable to STIs due to their unsafe and risky sexual behaviours (Nugraha, 2012; Abhinaja et al, 2013). In addition, the low risk groups may be infected from their partner who had sex with other people (Hargono et al, 2012; Khosidah et al, 2014).

A survey on reproductive health among women conducted by Rama Sesana Foundation in 2011, involving eight traditional markets in Denpasar City found that women assumed themselves as a low risk group even though they aware that their partner might had sex with other women. Furthermore, this survey also revealed that for those who scared of contracting HIV/AIDS, they were reluctant to use condom with their regular partner because they were afraid if their partner will be mad if they offered them to use condom. This survey confirmed that women who worked at the markets were vulnerable for contracting HIV and STIs. In addition, they seem to have little understanding on prevention measures for HIV and STIs (Dewi et al, 2013).

Out of 20 in-depth interview participants, 16 participants were the owner of goods or shop, two participants were shop assistance and two participants were market labourers. The majority of participants were from Karangasem District ( 9 people). The age of participants can be classified into: 18 - 25 years (6 people), 26 - 35 years ( 7 people) and above 35 years (7 people). Ten participants were married while another 10 participants were not married. The majority of participants were Balinese (15 people) and most of participants were only primary school graduates (8 people).

Our qualitative data analysis identified several themes in relation to high risk sexual behaviours and prevention measures undertaken by our participants as well as their perceived risk for contracting HIV and STIs.

The first theme was sexual intercourse with other man outside of their marriage. The basis for their sexual relation was mutual interests but not commercial purposes. Six participants admitted that they ever had or currently with other man who was not their husband. The following quote from NA illustrate this key theme. NA is a chicken meat seller at the market in the morning and admitted having a sexual relationship with one of her regular customers.

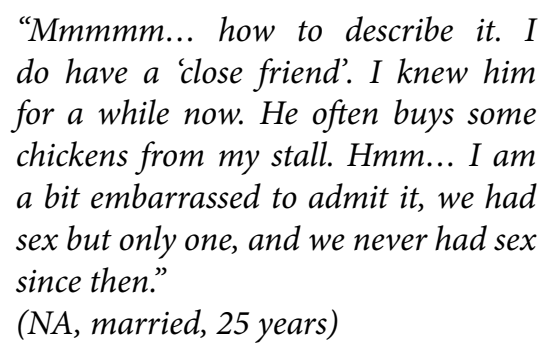

Another study in Mozambique in 2015 on association between individual perception and HIV and STIs transmission revealed that about $27 \%$ females and $80 \%$ males perceived themselves as a low risk group for contracting HIV and STIs, even though they are actually a high or moderate risk population. This study argues that level of knowledge is the key determinant for the uptake of HIV and STIs prevention behaviours in Mozambique (Prata et al., 2015).

Even though the pattern for sexual intercourse was based on mutual interest, there was however one participant who received money or gifts from her sexual partners. She admitted that she did this sexual transaction due to economic pressures. The following quote from RI, a soft-drink seller at night in the Badung Market, can illustrate the above point:

\section{"My boyfriend is busy. My new partner}


is very kind, he often gives me clothes, money, and many other things."

"Hahaha... Sure, we had sex, about two weeks ago. Yes, we used condom because I am afraid of getting pregnant. He often carries condoms with him, so basically he prepares for it hehehe ..."

"We usually had sex at my place or we rent a short-time accommodation just for having sex. There are plenty around Pidada or Ubung areas, cheap of course and he paid for it too." (RI, not married, 27 years)

Sexual behaviours determine someone's sexual and reproductive health. A study conducted in England by comparing behavior patterns of the population from National Survey of Sexual Attitudes and Lifestyles (Natsal) between 1990 and 2000. This comparison study only included male and female aged between 16-44 years who resided in England. All eligible participants were interviewed. This study found that the increase in condom use to prevent HIV and STIs was followed by the increase of risky and unsafe sexual behaviours (Johnson et al., 2001).

Indirect female sex workers in Semarang City showed that most female sex workers did not directly admit that they belonged to a high risk group but their knowledge and practice of STI prevention efforts was lacking. Although they agree with the use of condoms as a good prevention effort, but in practice when conducting sexual activity is not always the condom they use. Their bargaining position is still low in negotiating condom use with clients. While support from family and peers is weak in preventing STIs.

The next theme was risky sexual behaviours with the sexual partner outside of their marriage. Participants admitted that they rarely used condom or never used condom because their sexual partner did not want to use it. They also said that condom could reduce the satisfaction of their sexual partner, as can be seen in the following quote from AP, a fruit seller in the afternoon, and KW, a shop assistance at a vegetable stall in the morning.
"I never use condom with him, he does not like it, lack of satisfaction he said...."

(AP, not married, 19 years)

"I never use condom as I already use the 3-months injectable contraception. He also does not like using it."

( $\mathrm{KW}$, married, 45 years)

One participant admitted that she always used condom whenever she had sex with her affair, as can be seen in the following quote:

"Hahaha... Sure, we had sex, about two weeks ago. Yes, we used condom because I am afraid of getting pregnant. He often carries condoms with him, so basically he prepares for it"

(RI, not married, 27 years)

The third theme was the perceived risk for HIV and STIs acquisition. Interestingly, the majority of participants who had sex with their affair had low perceived risk for HIV and STIs acquisition. This was because they never had symptoms or signs on their reproductive organs or systems, therefore they assumed that they were not at high risk for STIs or HIV infection. This can be seen in the following quote:

"In my opinion, I am not at risk, there is no reason for the risk though. I have no symptoms or signs; therefore, I have no risk. If I do have symptoms on my reproductive organs, then $I$ am at risk...."

(KW, married. 45 years)

An uptake of HIV and STIs prevention measures are required if the transmission rates are about to reduce. A study in 2006 revealed that the main route for HIV and STIs transmission among housewives was via sexual intercourse with their infected husband. This survey involved 350 housewives in Mumbay - India. This study found that the uptake for HIV and STIs prevention measures among housewives in Mumbay was very low. They assumed that they were not at high risk if they only had sex with their husband. In addition, they also perceived themselves as a low risk group because they were not sex workers 
and they fully trust their husband. These assumptions lead to a low uptake of HIV and STIs prevention measures among housewives women in Mumbay (Chatterjee, 2006).

Similar study was conducted in Kenya to understand association between sexual behaviours and HIV and STIs transmission. This study reanalysed data from the 1998 Health and Demographic Survey of Kenya by employing a logistic regression model. This study found that there was a significant association between risky sexual behaviours and HIV or STIs transmission for both men and women. Several factors were identified as key determinants which were sociodemographic, level of knowledge, age, marital status, education level, employment status, residency, ethnicity, availability of information on HIV and STIs, and condom use (Akwara et al., 2015).

An increase in the incidence of STIs is influenced by several factors. These factors include age, education, behavior, work, spouse's job, number of marriages and personal hygiene level. One of the most powerful and irreversible predictor factors is age. Research conducted by Simanjuntak shows that age is significantly associated with HIV / AIDS which is included in the category of STI disease (Simanjuntak, 2010).

Participants who did not have a sexual affair admitted that they were probably at high risk due to their husband behaviours. They found out that their husband had an affair with other woman and this might increased their risk for contracting HIV and STIs. This can be seen in the following quotes from $\mathrm{WR}$, a fruit salad seller during the day and WR, a Hindu's offering seller at night.

"I never have an affair with other man... I am faithful to my husband hahaha ... But in the past, my husband had an affair with other women. He works as a taxi driver. I don't know how many affairs he had though, he had multiple affairs. I was really upset by it. When he had sex with other woman, he never used condom, and he also does not like using condom. The last affair was with a housewife and it really upset me."

(KM, married, 44 years)
"My boyfriend had an affair in the past. He said he lost his mind. He had an affair with a money lender at the market. That woman is a naughty girl. But now he is faithfull and not having an affair anymore. He fully regreted his action, it was 6 months ago."

"Sure, he did. He admitted he had sex with that woman. I caught them at her place, I was really mad and I grab her by her hair."

(WR, not married, 38 years)

In addition, several participants admitted that they might be at high risk for contracting HIV and STIs though they were unsure if their husband had an affair or not. They said that there is always possibility that their husband might do high risk sexual behaviours as can be seen in the following quote by NR, a market labourer in the afternoon.

\begin{abstract}
"Maybe I am at risk. Even though I am faithfull, but I do not know if my husband is faithfull or not. I do not know what he did outside the house. He said that he is faithfull. We cannot really trust it, nowadays there are many men with innocent face but their behaviors are not as innocent. Maybe they after sex from other women, we never know really hehehe ..."

(NR, married. 45 years)
\end{abstract}

Our study has several limitations. Firstly, we did not interview regular partner of our respondents. It is essential to understand sexual behaviours of their regular partner. Indeed, sexual behaviours of their regular partner might influence their decision on the uptake of prevention measures, especially condom use. Secondly, we conducted the interviews at the market settings for which our respondents were served the customers. Findings of our study suggest that prevention strategies especially for the general population or population which previously considered as low risk such as women who work at the markets are warranted.

\section{Conclusion}

Women who work at the markets, either as the shop/goods owner, shop attendance and 
market labourer, at the Badung traditional Market in Denpasar City perform some degree of risky sexual behaviours. They had sexual intercourse with other man outside of their regular sexual partner and rarely use condom. Furthermore, they assume themselves as a low risk group and have a low perceived risk for contracting HIV and STIs. Prevention programs targeting low risk groups are required if the burden of disease from STIs including HIV is about to reduce.

\section{Acknowledgements}

The authors would like to thank all respondents who had participated in our study. We also would like to thank Denpasar City Government who had supported our study.

\section{References}

Abhinaja, W., \& Astuti, A.S., 2013. Pengetahuan, Sikap Ibu Rumah Tangga Mengenai Infeksi Menular Seksual Termasuk HIV/AIDS Serta Perilaku Pencegahannya Di Kelurahan Sanur, Kecamatan Denpasar Selatan. Jurnal Community Health Unud, I(3), pp. 218-28.

Akwara, P.A., Madise, N.J., \& Hinde, A., 2015. Perception of Risk of HIV/AIDS and Sexual Behaviour in Kenya. Journal of Biosocial Science, 35(3), pp. 385-411.

Aryani, D., 2015. Perilaku Pencegahan Infeksi Menular Seksual Pada Wanita Pekerja Seksual Kabupaten Tegal. Jurnal Kesehatan Masyarakat, 10(2), pp. 160.

Chatterjee, N., Hosain, G.M.M., 2006. Perceptions of Risk and Behaviour Change for Prevention of HIV among Married Women in Mumbai, India. Journal Health Population Nutrition, 24(1), pp. 81-8.

Dewi, S., Wulandari, L., \& Karmaya, M., 2013. Laporan Hasil Penelitian Kerentanan Perempuan terhadap Penularan IMS dan HIV : Gambaran Perilaku Seksual Berisiko di Kota Denpasar. Public Health and Preventive Medicine Archive, 1.

Dinas Kesehatan Provinsi Bali., 2017. Data P2M
Dinas Kesehatan Provinsi Bali Tahun 2016. Denpasar.

Hargono, A., Tjipto, B.W., Roosihermiati, B., 2012. Kajian Kebijakan Penggunaan Data PapSmear Ibu Rumah Tangga dalam Surveilans Infeksi Menular Seksual pada Kelompok Risiko Rendah. Buletin Penelitian Sistem Kesehatan, 15, pp. 381-9.

Johnson, A.M., Mercer, C.H., Erens, B., Copas, A.J., Mcmanus, S., Wellings, K., 2001. Sexual Behaviour in Britain: Partnerships, Practices, and HIV Risk Behaviours. The Lancet, 358, pp. 1835-42.

Kementerian Kesehatan RI., 2014. Statistik Kasus HIV/AIDS di Indonesia s/d September 2014. Jakarta.

Khosidah, A., \& Purwanti, S., 2014. Persepsi Ibu Rumah Tangga Tentang Voluntarry Councelling and Testing (VCT) terhadap Perilaku Pencegahan HIV-AIDS. Jurnal Ilmu Kebidanan. 5, pp. 67-78.

Nugraha, P., 2012. Perilaku Wanita Pekerja Seks dalam Pencegahan Infeksi Menular Seksual (Studi Kualitatif Pada Anak Asuh di Lokalisasi Gembol, Sukosari, Bawen, Kabupaten Semarang). Media Kesehatan Masyarakat Indonesia, 11(1), pp. 71-74.

Prata, B.N., \& Morris, L., 2015. Relationship Between HIV Risk Perception And Condom Use: Evidence from a Population-Based Survey in Mozambique. Guttmacher Institute, 32(4), pp. 192-200.

Purnamawati, D., 2013. Perilaku Pencegahan Penyakit Menular Seksual di Kalangan Wanita Pekerja Seksual Langsung. Jurnal Kesehatan Masyarakat Nasional, 7.

Simanjuntak, E., 2010. Analisis Faktor Resiko Penularan HIV/AIDS di Kota Medan. Jurnal Pembangunan Manusia, 4(12), pp. 2. 